\title{
Journal of Reproduction $\mathscr{G}$ Fertility
}

Volume 60 (No. 2), November 1980

D. Whyman \& R. W. Moore. Effects of PMSG and the prostaglandin F-2 $\alpha$ analogue, cloprostenol, on superovulation, fertilization and egg transport in the ewe

N. C. Rawlings, L. Weir, B. Todd, J. Manns \& J. H. Hyland. Some endocrine changes associated with the post-partum period of the suckling beef cow

D. C. Wathes. Protein synthesis by bovine chorion and uterine endometrium during the period of implantation

E. L. Sheldrick, A. P. Ricketts \& A. P. F. Flint. Placental production of progesterone in ovariectomized goats treated with a synthetic progestagen to maintain pregnancy

D. M. Parry, D. L. Willcox \& G. D. Thorburn. Ultrastructural and cytochemical study of the bovine corpus luteum

M. L. Kaker, M. N. Razdan \& M. M. Galhotra. Serum LH concentrations in cyclic buffalo (Bubalus bubalis)

P. B. Gherardi \& D. R. Lindsay. The effect of season on the ovulatory response of Merino ewes to serum from pregnant mares

C. M. Howles, G. M. Webster \& N. B. Haynes. The effect of rearing under a long or short photoperiod on testis growth, plasma testosterone and prolactin concentrations, and the development of sexual behaviour in rams

M. T. Kane \& C. R. Headon. The role of commercial bovine serum albumin preparations in the culture of one-cell rabbit embryos to blastocysts

\section{Volume 61 (No. 1), January 1981}

B. P. Fitzgerald, J. D. Evins \& F. J. Cunningham. Effect of TRH on the secretion of prolactin in ewes at various stages of pregnancy and in non-pregnant ewes during the breeding season and seasonal anoestrus

B. P. Fitzgerald \& F. J. Cunningham. Effect of removal of lambs or treatment with bromocriptine on plasma concentrations of prolactin and FSH during the post-partum period in ewes lambing at different times during the breeding season

L. Adam, E. Aizinbud, A. Tadmor \& H. Schindler. Impedometric properties of the vulvar and vaginal tissues of ewes during the oestrous cycle

I. Wilmut \& D. I. Sales. Effect of an asynchronous environment on embryonic development in sheep

L. Dusza \& H. Krzymowska. Plasma prolactin levels in sows during pregnancy, parturition and early lactation

The Journal of Reproduction and Fertility is published every 2 months at $£ 16.00$

(U.S. $\$ 40.00$ ) per issue and $£ 85.00$ (U.S. $\$ 195.00$ ) per year by the

JOURNALS OF REPRODUCTION AND FERTILITY LTD

22 Newmarket Road, Cambridge CB5 8DT, U.K. (Editorial)

P.O. Box 32, Commerce Way, Colchester CO2 8HP, U.K. (Distribution) 


\section{THE \\ JOURNAL OF \\ AGRICULTURAL SCIENCE}

BDITED B Y

Prof. Sir J. W. L. BEAMENT, sC.D., F.R.s., Department of Applied Biology, Cambridge

G. D. H. BELL, C.B.E., PH.D., SC.D.(h.c.), D.sc.(h.c.), P.R.S., 6 Worts Causeway, Cambridge

SIR K. L. BLAXTER, PH.D., N.D.A. (HONS.), D.SC., F.R.S.E., F.R.S.,

Rowett Research Institute, Bucksburn, Aberdeen

G. W. COOKE, PH.D., F.R.I.C., F.R.S., Agricultural Research Council, 160 Great Portland Street, London, WIN 6DT

J. A. CUR R IE, PH.D., Rothamsted Experimental Station, Harpenden

S. K. ELTRINGHAM, PH.D., Department of Applied Biology, Cambridge

Prof. SiR J. B. HUTCHINSON, C.M.G., SC.D., F.R.s., Emeritus Professor of Agriculture, Department of Applied Biology, Cambridge

D. B. LIN DSA Y, B.SC., M.A., D.PHIL., Agricultural Research Council, Institute of Animal Physiology, Babraham, Cambridge

Prof. J. B. OWEN, B.SC., PH.D., M.A., The Department of Agriculture, Bangor

W. J. RIDGMAN, M.A., Department of Applied Biology, Cambridge

H. H. ROGERS, B.SC., DIP.AG.SCI., F.I. BIOL., Plant Breeding Institute, Cambridge

L. E. A. ROWSON, O.B.E., M.R.c.v.s., F.R.s., Cambridge and District Cattle Breeders

Limited, The Gravel Pits, Huntingdon Road, Cambridge

Prop. E. W. R USSELL, C.M.G., PH.D., P.INST.P., Department of Soil Science,

University of Reading

F. YATES, C.B.E., SC.D., F.R.S., Rothamsted Experimental Station, Harpenden

VOLUME 95

CAMBRIDGE UNIVERSITY PRESS

CAMBRIDGE

LONDON NEW YORK NEW ROCHELLE

MELBOURNE SYDNEY

1980 


\section{PUBLISHED BY}

THE PRESS SYNDICATE OF THE UNIVERSTTY OF CAMBRIDGE

The Pitt Building, Trumpington Street, Cambridge CB2 1RP

32 East 57th Street, New York, N.Y.10022

(C) Cambridge University Press 1980 


\section{Contents}

Part 1 (August 1980)

PAGE

Degen, A. A. and Youna, B. A. Live-weight, total body-water and maternal body-solid changes in pregnant and lactating beef cows.

Coward, B. JANE and Buttery, P. J. A perfused ruminant muscle preparation.

Colebrook, W. F. and Black, J. L. A note on a urine collection system for male pigs $\quad$. 17

Macleod, G. D. and ClaRK, J. A. An index of feather cover . . . . . . . . . 21

Pechan, P. M., Bashford, J. A. and Morgan, D. G. The use of radiography in studies of pod growth in oil-seed rape (Brassica napus L.) . . . . . . . .

Blackman, J. A. and Girl, A. A. A comparison of some small-scale tests for bread-making quality used in wheat breeding

Powell, Alison A. and MatThews, $\mathbf{S}$. The significance of damage during imbibition to the field emergence of pea (Pisum sativum L.) seeds . . . . . . . . . .

McArthor, I. D. Pre-lambing supplementation of gadic ewes in western Afghanistan . 39

Amir, D., Genizi, A. and Schindler, H. Seasonal and other changes in the gestation duration of sheep . . . . . . . . . . . . . . . . .

Natarajan, M. and Wirley, R. W. Sorghum-pigeonpea intercropping and the effects of plant population density. 1. Growth and yield

Natarajan, M. and Willey, R. W. Sorghum-pigeonpea intercropping and the effects of plant population density. 2. Resource use

SnNaH, S. Detection of components of genetic variation and genotype $\times$ environment interaction in spring wheat . $. \quad . \quad . \quad . \quad . \quad . \quad . \quad . \quad . \quad . \quad$.

L'Estrange, J. L. and Hanrahan, J. P. Some breed effects on the melting point and fatty acid composition of carcass fat in lambs

Fuller, M. P. and Eagles, C. F. The effect of temperature on cold hardening of Lolium perenne seedlings .

REID, D. The effects of rates of potassium application on the production and quality of herbage from a perennial ryegrass sward receiving a wide range of nitrogen rates .

KIRBY, E. J. M. and Ellis, R. P. A comparison of spring barley grown in England and in Scotland. 1. Shoot apex development

Ellis, R. P. and KrRBY, E. J. M. A comparison of spring barley grown in England and in Scotland. 2. Yield and its components .

Mohta, N. K. and DE, R. Intercropping maize and sorghum with soya beans . .
Gray, R. and McCracken, K. J. Effect of confinement in a respiration chamber and changes in temperature and plane of nutrition on heat production of $25 \mathrm{~kg}$ pigs

Price, J. and Humphries, W. R. Investigation of the effect of supplementary zinc on growth rate of beef cattle on farms in N. Scotland

RoBERTS, E. A. Stratification, covariance and weight gain in experiments with repeated observations .

Taparia, A. L. and Sharma, V. V. Some factors affecting voluntary food intake in buffaloes. 1. Effect of feeding long-chopped and ground roughages

Taparia, A. L. and Sharma, V. V. Some factors affecting voluntary food intake in buffaloes. 2. Effect of feeding mixed diets 
TaParia, A. L. and Sharma, V. V. Some factors affecting voluntary food intake in buffaloes. 3. Effect of concentrate feeding on intake of roughages fed to lactating buffaloes .' .

Singh, A. P., Sakal, R., Thakur, K. N. and Sinha, H. Response of wheat to zinc and its critical level in Old Alluvium soils

165

175

FINNEY, D. J. The estimation of parameters by least squares from unbalanced experiments Udo, E. J. Profile distribution of iron sesquioxide contents in selected Nigerian soils .

Prasad, R. and Singh, A. Relative efficiency of rock phosphate and superphosphate for forage legumes and residual effects on succeeding wheat

Kelada, N. L., GaABodb, I. A. and RawaSH, I. A. A comparison of the juvenilizing effect of six juvenile hormone-like activity compounds on Egyptian Culex pipiens $\mathrm{L}$.

Whitehead, A. G., Tite, D. J., Fraser, Janet E. and French, Eileen M. Effects of aldicarb and oxamyl in peaty loam soil on potato cyst-nematode, Globodera rostochiensis, and on resistant and susceptible potatoes

Buvanendran, V., Umoh, J. E. and Abubakar, B. Y. An evaluation of body size as related to weight of three West African breeds of cattle in Nigeria

\section{SHORT Notes}

Broad, T. E., Davies, A. S. and Liggins, G. C. Carcass composition of foetal lambs: effects of hypophysectomy and pituitary stalk-section

Armstrong, A. C. The interaction of drainage and the response of winter wheat to nitrogen fertilizers: some preliminary results

Roberts, E. A. Periodic regression in long-term agricultural experiments

Oldham, J. D., Bruckental, I. and Nissenbaum, A. Observations on rumen ammonia metabolism in lactating dairy cows

Osborne, B. G. and Watson, R. D. Analysis of ergots from winter wheat in northern Scotland

\section{Part 2 (October 1980)}

Murray, D. M. and Slezacek, Olga. Growth rate effects on some offal components of sheep

Davies, A. S., Pearson, G. and Carr, J. R. The carcass composition of male, castrated male and female pigs resulting from two levels of feeding

Hamilton, W. J. and Blaxter, K. L. Reproduction in farmed red deer. 1. Hind and stag fertility .

Blaxter, K. L. and Hamiton, W. J. Reproduction in farmed red deer. 2. Calf growth and mortality

Gray, D., Ward, J.A. and Steckel, Joyce R. A. Growth and development of bush tomatoes in relation to temperature

Whitehead, A. G., Tite, D. J., Fraser, Janet E. and French, Emeen M. Control of potato cyst-nematode, Globodera rostochiensis, in a three-course rotation

Morris, E. JANE. The cell walls of Eragrostis tef: variations in chemical composition and digestibility .

MorRIs, E. JANE and vaN GYLSWYK, N. O. Comparison of the action of rumen bacteria on cell walls from Eragrostis tef . 
KIRTLand, JANET and Gorr, M. I. Fat cell synthesis in pigs assessed after administration of tritiated thymidine in vivo

Aboul-Naga, A. M., Gabr, M. G. and EL-Shoвokshy, A. S. Using Suffolk sheep for improving lamb production from subtropical Egyptian sheep. 3. Ewe lamb performance .

GuIRaIs, R. A. Response to the use of Merino in improvement of coarse-wool Barki sheep: an analysis of some cross-bred wool traits .

Murray, D. M. and Slezacek, Olga. Growth pattern and its effect on feed utilization of sheep

Mavrogenis, A. P., Hancock, J. and Louca, A. The effect of body-weight changes during pregnancy and lactation on the performance of three breeds of sheep

325

333

339

349

357

Aboul-NagA, A. M. and AFTF, E. A. Crossing subtropical Egyptian sheep with Hampshire to improve their lamb production .

Ingram, D. L., Walters, D. E. and Legge, K. F. Variations in motor activity and in food and water intake over $24 \mathrm{~h}$ periods in pigs

MUtSaers, H. J. W. The effect of row orientation, date and latitude on light absorption by row crops

Angus, W. J. and Sage, G. C. M. Patterns of yield production in two semi-dwarf and two conventional height European spring wheats

Antoniewicz, Anna M., Hennemann, W. W. and Hanks, E. M. The effect of changes in the intestinal flow of nucleic acids on allantoin excretion in the urine of sheep . . .

Fisher, N. M. The effect of time of planting on four bean (Phaseolus vulgaris) genotypes in Kenya

TAYO, T. 0 . The response of two soya-bean varieties to the loss of apical dominance at the vegetative stage of growth

TownER, G. D. Towards more efficient soil-water modelling moisture profiles with constant surface water content

Farah, S. M. Effects of some cultural practices on yield and quality of flue-cured tobacco at Kenana Research Station

KEMPSTER, A. J., Cook, G. L. and Smith, R. J. The evaluation of a standardized commercial cutting technique for determining breed differences in carcass composition

365

371

381

387

395

401

417

Greenwood, D. J., Cleaver, T. J., Turner, Mary K., Hunt, J., Niendorf, K. B. and Loquens, S. M. H. Comparison of the effects of potassium fertilizer on the yield, potassium content and quality of 22 different vegetable and agricultural crops . .

Greenwood, D. J., Cleaver, T. J., Turner, Mary K., Hunt, J., Niendorf, K. B. and Loquens, S. M. H. Comparison of the effects of phosphate fertilizer on the yield, phosphate content and quality of 22 different vegetable and agricultural crops

Greenwood, D. J., Cleaver, T. J., Turner, Mary K., Hunt, J., Niendorf, K. B. and Loquens, S. M. H. Comparison of the effects of nitrogen fertilizer on the yield, nitrogen content and quality of 21 different vegetable and agricultural crops

TAYo, T. O. Compensatory growth and yield of pigeon pea (Cajanus cajan) following pod removal at different stages of reproductive growth

\section{SHORT Note}

Economdes, S. Factors affecting the performance of ewes fed ad libitum until weaning and the performance of their lambs 
Cowan, R. T., Robinson, J. J., McDonald, I. and Smart, R. Effects of body fatness at lambing and diet in lactation on body tissue loss, feed intake and milk yield of ewes in early lactation

Cowan, R. T., Robinson, J. J., McHatrie, I. and Fraser, C. The prediction of body composition in live ewes in early lactation from live weight and estimates of gut contents and total body water

Moustafa, Omayma K., El Attal, Z. M. and Abdallah, M. D. Du-ter as a synergist for insecticide formulations against cotton leafworm .

GLeeson, A. C. and McGrLCHRIST, C. A. Mixture diallel experiments with unequal proportions of genotypes.

Trovghton, A. Production of root axes and leaf elongation in perennial ryegrass in relation to dryness of the upper soil layer .

Wenham, G. and Wratre, R. S. A radiological investigation of the effects of cannulation on intestinal motility and digesta flow in sheep .

HendRICKsEn, R. and MrNson, D. J. The feed intake and grazing behaviour of cattle grazing a crop of Lablab purpureus cv. Rongai .

Sriskandarajah, N., Ashwood, A. and Kellaway, R. C. Effects of rolling and alkali treatment of barley grain supplements on forage intake and utilization by steers and lactating cows

Farmer, Linda J., Mackie, W. S. and Ritchie, P. J. Developmental changes in the biochemical composition of foetal and neonatal pig muscle with special reference to DNA synthesis

Penny, A., Widdowson, F. V. and Wrllams, R. J. B. An experiment begun in 1958 measuring effects of $\mathrm{N}, \mathrm{P}$ and $\mathrm{K}$ fertilizers on yield and $\mathrm{N}, \mathrm{P}$ and $\mathrm{K}$ contents of grass. 1. Effects during 1964-7

Penny, A. and Widdowson, F. V. An experiment begun in 1958 measuring effects of N, P and $\mathrm{K}$ fertilizers on yield and $\mathrm{N}, \mathrm{P}$ and $\mathrm{K}$ contents of grass. 2. Residual effects on arable crops, $1968-76$

Williams, Watkin and McGibbon, P. Environmental effects on seed oil percentage and fatty acid composition in white lupin (Lupinus albus) . . . . . . . .

Mangan, J. L., Jordan, D. J., West, JANeT and Webb, P. J. Protection of leaf protein of lucerne (Medicago sativa L.) against degradation in the rumen by treatment with formaldehyde and glutaraldehyde .

INNES, N. L. and WALKEY, D. G. A. The genetics of resistance to two strains of bean common mosaic virus in three cultivars of Phaseolus vulgaris $\mathrm{L}$. .

Grbb, M. J. and Treacher, T. T. The effect of ewe body condition at lambing on the performance of ewes and their lambs at pasture

Onwueme, I. C. and Fadayomi, O. A labour-saving system of yam (Dioscorea spp.) production through weed control with herbicides, the elimination of staking, and cropping at high density .

Corbet, Sarah A. and Wrllmer, P. G. Pollination of the yellow passionfruit: nectar pollen and carpenter bees

Ladamurn, J. C. The effect of time of harvest on the yield components of poppies (Papaver somniferum L.) 
Smrth, T., Broster, W. H. and Siviter, J. W. An assessment of barley straw and oat hulls as energy sources for yearling cattle

Smith, T., Broster, VAlerie J. and Hill, R. E. A comparison of sources of supplementary nitrogen for young cattle receiving fibre-rich diets

Olaboro, G., Campbell, L. D. and Marquardt, R. R. Performance of laying hens fed on diets containing heat-treated beans (Vicia faba L. var. minor), cotyledons and hulls .

Walkey, D. G. A. and Neely, Heather A. Resistance in white cabbage to necrosis caused by turnip and cauliflower mosaic viruses and pepper-spot

Stewart, R. H., Lynch, K. W. and White, Ethel M. The effect of growing clover cultivars in association with barley cultivars upon grain yield of the barley crop in the year of sowing and the subsequent year

\section{Short Notes}

Mitwal, J. P. Seasonal changes in semen characteristics of Marwari and Magra sheep of the Indian desert

OJeniyi, S. O. and AgBede, O. O. Agri-silviculture in Nigeria: food crops and soil fertility . 721

Fujihara, T. The eating and rumination behaviour in sheep fed only grass diets in either the fresh or dried form

Saha, S. N. and Bhargava, S. C. Physiological analysis of the growth, development and yield of oil-seed sesame. 
Continued from back cover.

ONWUEME, I. C. and FADAYOMI, O. A labour-saving system of yam (Dioscorea spp.) production through weed control with herbicides, the elimination of staking, and cropping at high density

Corbet, Sarah A. and Willmer, P. G. Pollination of the yellow passionfruit: nectar, pollen and carpenter bees .

LAUGHLIN, J. C. The effect of time of harvest on the yield components of poppies (Papaver

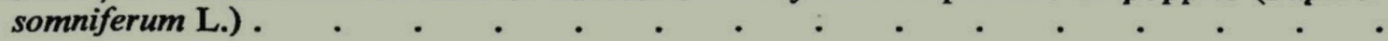

SMith, T., Broster, W. H. and Siviter, J. W. An assessment of barley straw and oat hulls as

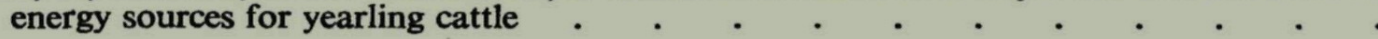

Smith, T., Broster, Valerie J. and Hill, R. E. A comparison of sources of supplementary

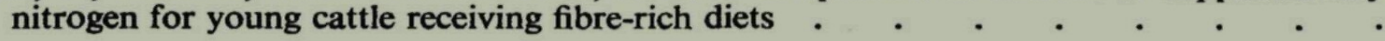

Olaboro, G., Camprell, L. D. and Marquardi, R. R. Performance of laying hens fed on diets containing heat-treated beans (Vicia faba $\mathrm{L}$. var. minor), cotyledons and hulls . .

Walkey, D. G. A. and Neely, Heather A. Resistance in white cabbage to necrosis caused by

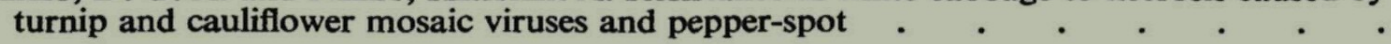

STEWART, R. H., LYNCH, K. W. and WhITE, ETHEL M. The effect of growing clover cultivars in association with barley cultivars upon grain yield of the barley crop in the year of sowing and the subsequent year.

\section{SHORT NOTES}

MrtTaL, J. P. Seasonal changes in semen characteristics of Marwari and Magra sheep of the Indian desert.

OJENIYI, S. O. and AgBede, O. O. Agri-silviculture in Nigeria: food crops and soil fertility .

FuJIHARA, T. The eating and rumination behaviour in sheep fed only grass diets in either the fresh or dried form.

SaHa, S. N. and Bhargava, S. C. Physiological analysis of the growth, development and yield of oil-seed sesame 


\section{THE JOURNAL OF AGRICULTURAL SCIENCE}

\section{CONTENTS}

\section{Vol. 95 Part 3 December 1980}

Cowan, R. T., Robinson, J. J., MCDonald, I. and Smart, R. Effects of body fatness at lambing and diet in lactation on body tissue loss, feed intake and milk yield of ewes in early lactation

Cowan, R. T., Robinson, J. J., McHattie, I. and Fraser, C. The prediction of body composition in live ewes in early lactation from live weight and estimates of gut contents and total body water

Moustafa, Omayma K., El Attal, Z. M. and Abdallah, M. D. Du-ter as a synergist for insecticide formulations against cotton leafworm

Gleeson, A. C. and McGilchrist, C. A. Mixture diallel experiments with unequal proportions of genotypes

Trougrton, A. Production of root axes and leaf elongation in perennial ryegrass in relation to dryness of the upper soil layer .

Wenham, G. and WyBurn, R. S. A radiological investigation of the effects of cannulation on intestinal motility and digesta flow in sheep

HENDRICKSEN, R. and Minson, D. J. The feed intake and grazing behaviour of cattle grazing a crop of Lablab purpureus cv. Rongai . . . . . . . . . . .

Sriskandarajah, N., Ashwood, A. and Kellaway, R. C. Effects of rolling and alkali treatment of barley grain supplements on forage intake and utilization by steers and lactating cows

FARMER, LINDA J., MACKIE, W. S. and RITCHIE, P. J. Developmental changes in the biochemical composition of foetal and neonatal pig muscle with special reference to DNA synthesis .

Penny, A., Widdowson, F. V. and Williams, R. J. B. An experiment begun in 1958 measuring effects of $N, P$ and $K$ fertilizers on yield and $N, P$ and $K$ contents of grass. 1. Effects during 1964-7

PENNY, A. and Wmbowson, F. V. An experiment begun in 1958 measuring effects of N, P and $\mathrm{K}$ fertilizers on yield and $\mathrm{N}, \mathrm{P}$ and $\mathrm{K}$ contents of grass. 2 . Residual effects on arable crops, 1968-76

WILliams, WATKIN and MCGIBBON, R. Environmental effects on seed oil percentage and fatty acid composition in white lupin (Lupinus albus)

Mangan, J. L., Jordan, D. J., West, Janet and WebB, P. J. Protection of leaf protein of lucerne (Medicago sativa L.) against degradation in the rumen by treatment with formaldehyde and glutaraldehyde.

INNES, N. L. and WALKEY, D. G. A. The genetics of resistance to two strains of bean common mosaic virus in three cultivars of Phaseolus vulgaris $\mathbf{L}$.

GiBs, M. J. and Treacher, T. T. The effect of ewe body condition at lambing on the performance of ewes and their lambs at pasture.

Continued on inside back cover

(C) Cambridge University Press 1980

SUBSCRIPTIONS. Two volumes of three parts are published annually. All orders must be accompanied by payment. The subscription price of volumes 94 and 95,1980 , is $£ 32.50$ net (U.S.A. and Canada US \$94.25) per volume (post free); single parts are available at $£ 13.00$ net (U.S.A. and Canada US $\$ 40.00$ ) plus postage. Orders or enquiries may be sent to any bookseller or subscription agent, or Cambridge University Press, P.O. Box 110, Cambridge CB2 3RL (U.S.A. and Canada, Cambridge University Press, 32 East 57th Street, New York, N.Y. 10022, U.S.A.). 